\title{
Contextualization of Tarekat In Modern Society: Study of the Spiritual Education of the Naqsyabandiyah Pauh In Padang, West Sumatra
}

\author{
Nunu Burhanuddin ${ }^{1}$, Willy Oktaviano ${ }^{2}$, Usman Syihab ${ }^{3}$, Ghilmanul Wasath ${ }^{4}$ \\ \{nunu.burhanuddin@iainbukittinggi.ac.id ${ }^{1}$, willyoktaviano@uinjkt.ac.id², \\ usmansyihab@uinjkt.ac.id ${ }^{3}$, ghilmanul.wasath@uinjkt.ac.id $\left.{ }^{4}\right\}$ \\ Institut Agama Islam Negeri (IAIN) Bukittinggi, Indonesia ${ }^{1}$ \\ Islamic Studies Faculty of UIN Jakarta, Indonesia ${ }^{2,3,4}$
}

\begin{abstract}
The order of modern society is faced with a mentality-psychological imbalance in the form of feeling dissatisfied, upset, less happy to feel unhappy with anything that has been obtained. This imbalance causes modern humans to be trapped in the dynamics of absurd mater-ialism which leads to a counterproductive attitude to life. The presence of religion which is encapsulated in the faces of tarekat institutions is alleged to be able to color human actions and behavior. Thus, spiritual education is an inseparable part of the education values that are oriented to physical development, intellectuality and the process of transforming individuals from dirty souls to clean souls in the context of qurbah to God. The article entitled Contextualization of Tarekat in Modern Society: The Study of Spiritual Education of the Naqsyabandiyah Pauh Tarekat in Padang, West Sumatra aims to unravel the strategic role of the Naqsyabandiyah Pauh city of Padang in the field of spiritual education in the face of the onslaught of moderation. The results of the analysis show that the teachings and ritual practices of the Naqsyabandiyah Pauh Tarekat in Padang have exposed the values of spiritual education, namely taubat, muraqabah, musyahadah, prayer and zikr, tasawwur al-Shaikh, and riyadhah.
\end{abstract}

Keywords. Modernity, Naqsyabandiyah Tarekat, and Spiritual Education

\section{Introduction}

The spiritual crisis that afflicts modern society has led to a symptom that seems to be the current trend, namely that people begin to turn to the esoteric dimension as an option to face the onslaught of modernity. The glamorous face of modernism with the foundation of rationality was allegedly carrying a very strong negative effect. This form of rationalism thinking has forced humans to struggle in a very complex life crisis. In general, the current crisis era can be seen from the emergence of global conflicts of disagreeable ideologies, spiritual confusion caused by the sophistication of modern science, challenges to moral and ethical values continue to evolve, as well as an instant pattern of life that attacks mentality and psychology. In this connection, talking about peace is in progress, even though such peace is not the result of anxiety, fear, doubt, injustice and arbitrariness. Also, talking about prosperity is trending the topic, even though poverty and oppression continued before our eyes. On the other hand, equality of rights is elaborated as an argument to punish the "superiority and strength" of others, 
so that the dictum of freedom becomes a powerful weapon to suppress other human initiatives. The problem of this modern society does not stop at the idealistic level regar-ding the concept of spiritual and material balance. This is because the problem of the spiritual crisis [1] has raised another problem that is no less dangerous, namely the social crisis.

One of the efforts taken to fight against hegemony and the onslaught of democracy is carried out by taking a mystical path, such as Sufism and tarekat. According to Donald Walters in the Crisis in Modern Thoughts, that as a result of the conditions of modernity, human begins to need a strong foundation for the order of morality, which is not derived from the physicalmaterial-istic order. One way is to return to traditional science, which begins the search for universality by learning special things through personal experience as individuals, and not with blurred entities, namely society. Only in humans is the key to meaning in this relative world where answers can be found. Walter's statement above shows that the practice of Sufism and tarekat as traditional science can be an option to liberate humans from the shackles of modernity [2]. In this case, the Naqsyabandiyah Pauh tarekat in Padang is one of the tarekat institutions in West Sumatra which directed its congregation to reach the level of spirituality in the form of closeness to Allah.

\section{Sketch Of Modern Society}

In a post-modernist perspective, moderni-zation can be called a spirit that is presumed to encourage the intellectual community in achieving progress. In the perspective of postmodernists, it is the spirit to achieve progress and human-ization of human spirit enshrined the belief which is very optimistic about the power of the human ratio. According to Fazlur Rahman, modernization is understood as an open attitude towards the West and therefore, it is more appre-ciative towards intellectualism [3]. Similar opi-nions are expressed by Amin Abdullah who interprets modernization as recognition of the power ratios in all human activities. Human with the ratio, of course as a subject; the giver of form and color on reality is direction of the historical development. The human ratios are considered to be able to dig the factual fact to find laws or the basics of universal and essential from reality [4].

From some of the views above, it can be understood that the realities of modern life and modernization is alleged to have transformed hu-man from social, economic, and cultural back-wardness. This is due to the modernization offers significant changes in human life, espe-cially the change of behavior which tends to be rational. In this regard, there are three traits of modernity that encourages humans to more advanced, while reacting to it as a challenge. These three features are rationalism, secularism, and scientism. mMeanwhile, the question of the spirit-uality values that is ppreciated by modern society shows tremendous attention as part of stabilization in guarding the life of materialistic. Jhon Naisbitt and Patricia, for example, through the Mega Trend 2000 echoed the famous motto of Spirituality Yes, No Religion [5]. Hermeneu-tically, this spirit shows the negative image of modern society who is experiencing loneliness and misery in their living spaces. Modern soci-ety is experiencing a drought the meaning of life within the structure of the society. In other words, modern society is experiencing symp-toms of psychological dislocation, disorienta-tion, and relative deprivation, which are stated by Eric Formm [6] as a society that is alienated from personal and from members of the society. 
In the brilliance of the material as a result of modernity, modern society who feel estranged in society required something as a handle for a living. They were flocking to look back - the root of the teachings that is missing from their lives. Their method of operation was the funda-mental teaching of religion and tradition. The Group was then known as the House of funda-mentalists [7]. The spiritual awakening in the modern era which takes the pattern of fundamen-talism shows that cultures and emotions psychiatric of modern society are authoritarian, intolerant, and vibrant force in showing himself against other communities [8] even rarely anar-chy against himself. It's just that, an offer which is displayed by the fundamentalists less so have a place, not only by groups outside of them, even of the same faith with them. In the view of Robert N. Bellah [9] modern society which prioritizes the pattern of scriptualists, fundamen-talist group, has limited opportunities to understand the values and teachings contained in a religion or tradition. In a straightforward language, Bellah says as follows, "that scripturalism has not met all religious need however successful it is as an ideology. It is difficult to imagine that an intransigent literalis can cope with the profound problem raised by modern experience in the mind of manajemen those best educated in the Islamic traditions [9].

In this context, the modern society needs more than what is offered by fundamentalism and scriptualists. Is not an exaggeration to say that modern society requires more intense religious experience in the search for the meaning of life, a touch that leads to peace and quiet. Many cases among the modern society in the West where the peak of material satisfaction have been felt and even no longer can be enjoyed, except on the outside of the material. Its material eroded its meaningfulness in as much as they experience spiritual condition distress. This con-dition is described as a result of failure in investing meaningful life, not find a source of happiness, hope, love and loss of strength for connection of comfort life [10]. In other cases, modern society feels lonely at the crowded mo-ment, feels the darkness when the world emits the glamour, feels a lack of abundant material life, even feeling uneasy when the audiences cheer and adore them [11]. This happens because the basic nature of the material which is a source of happiness is limited by space and time, so that it requires another source of happiness which is essentially unlimited, one of which is the aspect of spirituality. On this basis, the pattern of religious experience needed by modern society can be found in the activities of sufism and tarekat. The pattern of sufism and tarekat is more capable of appreciating modern life so that it has answers to every modern problem which is seen as ability to answer the problem of spirituality in modern society that has been formulated contextually, humanist-socio-logically, and has social salvation without leaving individual spiritual depth.

\section{The Profile Of Naqsyabandiyah Tarekat In Pauh, Padang}

One of many areas inhabited by adhe-rents of the society, including Naqsyabandiah tarekat is a region of West Sumatra. Naqsya-bandiah Tarekat is estimated to have first appeared in this region in 1850 AD. This tea-ching was brought by Sheikh Isma'il from Sinabur which was later disseminated by his stu-dents, among them are Sheikh Tuanku Berulak who died in the mid 1860's [12]. In Padang, these teachings brought by Sheikh Mohammed Thaib (18701944 M), a citizen of Pasar Baru, Padang, who was long enough to study in Mecca. After coming back from Mecca in 1905 AD, Syeikh Mohammad Thaib developed the teaching of this tarekat by approaching the society politely and friendly, so that his doctrines were accepted 
quickly by them. In 1911 AD, Syaikh Thaib built Surau which were the place to teach the doctrines of Naqsya-bandiah. These Surau were then known as Surau Baru and Baitul Makmur which were still exsist to this day. The spiritual activities of Naqsyabandiah such as suluk, wirid, tawajjuh and religious lectures still continued until the tarekat was led by the current murshid, namely Buya Syafri Malin Mudo (Interview with Syafri Malin Mudo, 2017). And the genealogy of the Naqsyaban-diyah Surau Baru and Baitul Makmur Padang from the Abu Bakar As-Siddiq gold chain to Syafri Malin Mudo who is now the Mursyid or leader of the Tarekat. From this genealogy it can be understood that the Naqshabandiyah Tarekat as a Tarekat that has a complete, strong and conti-nuous sanad until the noble friend of Abu Bakr as-Siddiq and the Messenger of Allah.

\section{Spiritual Education In The NaqsyabandiyahnTarekat, Pauh, Padang}

\subsection{Tarekat as a Spiritual Institution}

In its journey, initially, the practice of tasawwuf was an individual phenomenon that emphasized the behavior of zuhud as part of the example of the life of the Prophet Muhammad SAW. Over time, precisely in the 5th and 6th Hijriyah, the Islamic Sufi elites instituted their spiritual teachings in a practical mystical system [13], so that they were easily practiced by their followers. This mystical system contains the teachings about maqamat, a stages that are gradually followed and practiced by the Sufis to get to the level of closeness to Allah Azza wa Jalla, and ahwal, which is a psycho-spiritual condition that allows the tarekat participants (sâlik) to feel spiritual pleasure as a manifestation of ma'rifat towards Allah Azza wa Jalla [14]. Here, the tare-kat can be called a mazhab Sufistic that reflects a product of thought and technical mystical doctrine to provide certain spiritual methods for those who want closeness to Allah Azza wa Jalla. Therefore, tarekat can be seen as a dual phenomenon; first, becoming a mystical discipline that is normativ-ely-doctrinal includes the wirid system, zikir, do'a, tawassul ethics, pilgrimage, and the other as a Sufi spiritual path; while on the other hand is an institutional system that is integrated in a Sufistic system of life that creates individual and commu-nal transitions to achieve ultimate happiness, world-hereafter. These two sides (doctrinal and institutional) are intercorrelated and certainly cannot be separated from each other. At this level, the Naqsyabandiyah Pauh can be formulated into an effort to contextualize the teachings in order to be able to provide a set of spiritual curriculum for its students.

\subsection{Spiritual Education and Control of the Soul}

It is undeniable that the passing of mo-dernization in a society that is so fast is alleged to have changed the paradigm of society to be all materialistic and hedonic. No exception is the condition in the community in Pauh, Padang, which has come in contact with the practices of modernism which is characterized by the enormity of technological development in various fields. Although human beings experience tremendous material advances quantitatively, they experience a crisis that cannot be avoided qualitatively. World advancements accompanied by prosperity and various easy living facilities are allegedly raising new problems in the form of spirituality poverty. The progress of science and technology that is not accompanied by mental 
maturity, as said by Nurcholis Madjid, will be a time bomb for humans that can endanger their lives [15].

This opinion gets justification from several psychologists who stated that most of the psychiatric disorders experienced by modern hu-mans, such as anxiety, life boredom, stress, or deviant behavior caused by uneasy soul. Such conditions in turn bring up the phenomenon of self-bitterness caused by psychological factors. At this level, the emergence of efforts to avoid these disturbances that can be pursued through the approach of spiritual education becomes some-thing urgent to do. In connection with Islamic teachings --which are an integral part of Naqsya-bandiyah-emphasize the enforcement of the prin-ciple of balance, namely the balance and harmoni-zation between physical and spiritual, physical and spiritual.

Today, Islamic education is considered by some people to be suspected of experiencing a deadlock in carrying out the mission of Islam, namely to form a generation of Muslims who have noble character. Many people consider this failure to be triggered by an inappropriate education paradigm. The existing paradigm is considered more oriented to memorization and understanding, not attitudes and behavior. The target of education only touches the cognitive domain, does not reach psychomotor, especially affective. In the context of Islam, spiritual education can be carried out with various methods - one of them through the tarekat - becoming an offer for modern society. According to Said Hawa, the Sufis have inherited an education and purification strategy from the Prophet. [16] They studied spi-ritual education through Sufism for centuries and practiced it. To develop individual spiritual poten-tial, it can be done by following the practices of Sufism such as zikir, prayer, taubat, and so on. Sufism which emphasizes such practices and suluk in the treasures of Sufism is called tasawuf amali which is later institutionalized in the tarekat. In this connection, Syafri Malin Mudo said: "The divine awareness and commitment formed in the Naqshabandiyah Tarekat will be a control and selfcontrol of deviant behavior. The religious values instilled through education and religious activities will be a reminder for the pilgrims of tarekat from all of daily attitudes and behavior." (Interview with Syafri Malin Mudo 2017)

\subsection{Types of Spiritual Aducation}

Some of the practices in the Naqsya-bandiyah Pauh in Padang were used in the context of spiritual education, including taubat, muraqa-bah, musyahadah, prayer and zikr, tasawwur alShaikh, and riyadah.

First, Taubat. The initial stage in entering the tarekat starts from taubat, which is to admit, regret, and commit not to repeat acts that are contrary to the syariat. Taubat is a part of human effort to purify the soul of the traits that are not commendable and then to enter into the good deeds and praiseworthy. In the tarekat, taubat does not only regret the sins that have been committed, but follows the guidance of the mursyid as a spiritual guide. Taubat as a method of purifying the soul is presumably very influential for the improvement of one's behavior and personality. By doing taubat, the human spiritual will be pure like a newborn baby. This is as acknowledged by Syafri Malin Mudo, that "the human soul that has entered into taubat and is under the guidance of a mursyid, even though it has previously sinned, it will become clean like a white cloth that has not been tarnished" (Interview with Syafri Malin Mudo, 2017).

Second, Muraqabah. As tarekat that has been recognized for its validity, Naqsyabandiyah Pauh in Padang developed the aspect of mujâhadah, namely the pattern of approach to Allah SWT by relying on sincerity in worship, so that a servant will be able to climb the muraqabah level, a closeness to Allah as close as possible. Broadly, mujâhadah is a sincere effort in combating lust, desires, and all kinds of personal ambitions in order to the soul become pure 
and clean. It is likened to the glass which can immediately capture anything that is sacred, the person who performs mujahadah has the right to obtain various essential knowledge about Allah and His greatness. In the Qur'an, it is stated: "And those who strive for (seeking pleasure) us, We will truly show them our ways and indeed Allah is truly with those who do good." Q.S. Al-Ankabut: 69. The mujahadah aspect was carried out after the salik emptied themselves of all immor-ality. From this basis, Syafri Malin Mudo said, "After being cleansed of spiritual impurities, then trying earnestly by filling ourselves with noble behavior, such as sincerity, tawadhu ', patience, gratitude, qanaah, tawakkal, pleasure and so on" (Interviewed with Syafri Malin Mudo, 2017). On another occasion, Syafri Malin Mudo said that "Tarekat is an effort to reach qurbah, the close-ness to Allah, as close as possible. These efforts can be done through the muraqabah and musya-hadah methods. From this statement, it can be understood that the Naqshabandiyah Tarekat app-lied two methods in the operation-oriented app-roach to Allah, namely murâqabah and musyâ-hadah.

Third, Musyahadah. The level of the plague to reach the degree of closeness to Allah SWT as close as possible is also done by the method of musyahadah. The efforts of the tarekat experts that can reach closeness to Allah SWT is done through efforts to witness Allah, an effort and hard work done by the servant towards his Khaliq. This is as stated by Syafri Malin Mudo as follows, "Tarekat is an effort to achieve closeness with Allah SWT as close as possible. After muraqabah's efforts are carried out, the next step is achieving closeness through musyahadah"(Interviewed with Syafri Malin Mudo, 2017). The level of musyahadah as said by Syafri Malin Mudo is an amaliah based on the experien-ce of Abu Bakr as-Siddiq. Abu Bakr was closest to the Messenger of Allah, the earliest convert to Islam and was known to be the honest person. Honesty of Abu Bakr even became a spiritual prototype for the followers of this tarekat. The closeness of Abu Bakr and Allah SWT gives inspiration that such closeness can have implica-tions for the emergence of spiritual experiences as well as representing honest, true and characteristic behavior. At this point the relevance of the community can portray the presence of Allah SWT in various activities so as to produce complete behaviors.

Fourth, Doa and Zikir. In the practice of tarekat, mursyid has an important role in the spiritual formation of stu-dents. In addition to providing guidance directly through recitation or talqin and wirid, mursyid always prays for his students so that his soul becomes clean and peaceful. Prayer from murshid is an important element in the tarekat and is seen as influencing the hierarchy of the mental deve-lopment of the students. About this Syafri Malin Mudo said, "In an effort to purify the mentality of the students, I always pray for the students on every occasion. Especially for students who are far away, besides routine prayer, I also read a special prayer for them." (Interviewed with Syafri Malin Mudo, 2017). The adherents of the Naqshabandiyah Tarekat believe that the path to Allah is as much as a human breath. That is, to get to Allah, there are many ways that can be done, not necessarily by reaching mortal ', but the most important way is to always remember Allah with zikr [17]. Transmission of zikr which serves to arouse awareness of Allah, an awareness that will be a control for human behavior. The thicker the awareness, the more controlled the behavior. And zikir activity is also allegedly able to bring out a peace of mind, far from complicity, and easily to solve the problems faced because of growing optimistic nature. It is as stated by Ibn al-Qayyim that there are seventy benefits of zikir; some of them are zikir which can cause the heart free from the taint of immorality and zikir is the cause of the decline of grace and serenity. Similar with the theory of Al-Ghazali who said that zikir has a strong spirit, rich in heart, and graceful [18]. This is as Syafri Malin Mudo said, that "zikir can influence the strengthening of faith in Allah, build a good mindset and avoiding bad characteristic" (Interviewed with Syafri Malin Mudo, 2017). 
Fifth, Tasawwur al-Shaikh. Tasawwur al-Shaikh Tasawwur al-Shaikh in tarekat is often also called rabitah which means bond or connection. In the term tarekat, rabitah is often interpreted as a bond or spiritual connection between the mursyid and the student. The method of doing rabitah is to imagine the mursyid being in front of the student both when doing zikir or outside of doing zikir, so that it is as if the teacher always guides each student's steps. Thus, students always feel guided and supervised by the teacher in order that they will not do things outside obedience to the teacher. Rabithah is also an attempt to instill the teacher's example to students. By always imagi-ning the teacher (tashawwur al-shaykh), students will always try to remember and emulate every word and deed of the teacher. The stronger the murshid's inner bond with students, the faster he will lead to Allah SWT. This practice of tasawwur al-Shaykh is taught to every adherents of the Naqsyabandiyah Pauh Padang. This practice must be carried out every time you apply the wirid and it is recommended to set it every time outside wirid. The goal is that the tarekat students feel always connected to their mentality with the light of the mursyid teacher. The practice of ta-shawwur al-Shaykh among the adherents of the Naqsyabandiyah tarekat can be seen by the exposure of the photo of Shaykh Angku Munir in the Baitul Makmur mosque and Surau Baru Pauh in Padang. Of course the value of education from this practice is manifested in taking the example of the teacher, so that the adherents of the tarekat can be consistent in their simplicity and character starting from what the teacher has.

Sixth, Riyadhah. Riyadhah can be interpreted as an exercise to exercise self-control and hold back desire from momentary desires and pleasures. Through riya-dah, it is hoped that it can make the heart and soul clean and pure from all worldly interests. In the Naqsyabandiyah tarekat, riyadah is done in various forms such as fasting in a certain amount of time, holding back sleep, avoiding certain foods, modest dressing, simple living quarters, and others. Through riyadah, it is intended that the students, sâlik, can refrain from enjoying food, so eating activities are not to seek pleasure but because of necessity. By doing so, it is hoped that the salik can refrain from all consumptive activ-ities to seek worldly pleasures. In this case, the simplicity of Buya Syafri Malin Mudo, as the current leader of tarekat, can be seen clearly in the clothes worn and the sleeping mattresses - which are located next to the mihrab. The practice of the riyadhah which refers to simplicity can also be seen from the behavior of the students, the followers of the tarekat which are carried out with great willingness (Interview with Abduh, 2017). The urgency of the riyadhah as stated by Abu Ali ad-Daqqaq, the teacher of Imam al-Qusyairi, "Man jayyana dhahiruhu bi al-mujaha-dah hassanallahu sarâirahu bil bi almusya-hadah, wa'lam anna man lam yakun fi bidayatihi shahiba mujahadatin lam yajid min hadihit thariqtihi: Who decorates lahiriyah with muja-hadah Allah beautifies his heart with the ability to musyahadah (witnessing to His majesty with his heart, watching the unseen as clearly as his outer eyes see). And know that those who are not mujahadah at first, they will not taste the fragrant scent in the tarekat. Thus, riyadah which is done with sincerity can keep someone from making mistakes, both to humans and other creatures, especially to Allah Azza wa Jalla so that it beco-mes a means to deliver someone to self-impro-vement.

\section{Conclusion}

From the description above, it can be con-cluded that modernity with all its complexities presents tremendous challenges that can erode the mentality, emotionality and human psychology. Such conditions occur due to failure to invest meaningful life, so as not to find the source of happiness. It is not uncommon for modern prob-lems to cause people to be depressed, 
feel lonely when they are busy, feel darkness even though the world emits glitter, even feel a lack of abundant material life. This happens because the nature of the material which is the source of happiness is limited by space and time. It is at this point that humans need another source of happiness whose basic nature is unlimited, one of which is the aspect of spirituality. It is at this point that the Naqsyabandiyah Pauh Tarekat in Padang is expected to provide a solution for spiritual education to minimize the onslaught of modernity. This hope is not excessive because in this tarekat there are prac-tices which could be used within the framework of spiritual education, namely the practice of taubat, muraqabah, musyahadah, prayer and zikr, tasawwur al-Shaikh, and riyadah. With this edu-cational model, modern society - especially the people in West Sumatra - is expected to live a life full of meaning and be protected from the onslaught of moderation.

\section{References}

[1] Tri Astutik Haryati, “Modernitas Dalam Perspektif Seyyed Hossein Nasr,” Penelitian, vol. 8, no. 2, pp. 307-324, 2011.

[2] Ahmad Sidqi, "Wajah Tasawuf di Era Modern, Antara Tantangan dan Jawaban," Epistemé, vol. 10, no. 1, 2015.

[3] Safet Bektovic, "Towards a neo-modernist Islam Fazlur Rahman and the rethinking of Islamic tradition and modernity," Stud. Theol. - Nord. J. Theol., vol. 70, no. 2, 2016.

[4] M. A. Abdullah, Falsafah kalam di era postmodernisme. Pustaka Pelajar, 2007.

[5] Amsal Bakhtiar, "Agama Dalam Pandangan Futurolog," Kanz Philosphia A J. Islam. Philos., vol. 3, no. 2, 2013.

[6] Kasiyan, "Media di Era Massa: Tegangan Antara Berkah dan Kutukan Bagi Humaniora," Ornamen, vol. 3, no. 1, 2006.

[7] Akbar S Ahmed, Post Modernisme. New York: the Taylor \& Francis e-Library, 2003.

[8] Muzaini, "Perkembangan Teknologi Dan Perilaku Menyimpang Dalam Masyarakat Modern," J. Pembang. Pendidik., vol. 2, no. 1, 2014.

[9] Robert N Bellah, Beyond Belief. Paramadina \& The Ford Foundation, 2000.

[10] Barbara Hemphill, Spiritual Assesments in Occupa-tional Thrapy. Westren Michigan University, 2015.

[11] Abdul Mujib, "Implenetasi Psiko-Spiritual Dalam Pendidikan Islam Abdul Mujib," MADANIA, vol. 19, no. 2, pp. 195-206, 2015.

[12] Martin Van Bruinessen, Tarekat Naqsyabandiyah di Indonesia. 1992.

[13] M. Khasan, "Pesantren, Sufisme dan Tantangan Modernitas," Dimas Pemikir. Agama untuk Pember-daya., vol. 10, no. 1, pp. 111-132, 2010.

[14] M. Awaludin, "SEJARAH DAN PERKEMBANGAN TAREKAT DI NUSANTARA," Al-Afkar, vol. 5, no. 2, 2016.

[15] Nurcholish Madjid, Islam Doktrin dan Peradaban. Jakarta: Yayasan Paramadina, 2006.

[16] Fathur Rohman, "Pendidikan Spiritual Berbasi Tareket Bagi Pecandu Narkoba (Studi Kasus di Pondok Pesantren As-Stressiyah Darul Ubudiyah Sejati Sejomulyo Juwana Pati),” J. Pendidik. Agama Islam, vol. 5, no. 2, pp. 164-180, 2017.

[17] Syafruddin, "Pendidikan Karater Melalui Zikir," Fakt. J. Ilm. Kependidikan, vol. 4, no. 3, pp. 291$300,1017$.

[18] Quraish Syihab, Wawasan Al-Quran. Jakarta, 2008. 